\title{
A new species of the zephyrinid nudibranch genus Janolus (Mollusca: Nudibranchia) from North America and Costa Rica
}

\author{
Yolanda E. Camacho-García ${ }^{1}$ \& Terrence M. Gosliner ${ }^{2}$ \\ 1 Museo de Zoología, Escuela de Biología, Universidad de Costa Rica, San Pedro de Montes de Oca, San José, Costa \\ Rica; ycamacho@biologia.ucr.ac.cr \\ 2 Department of Invertebrate Zoology and Geology, California Academy of Sciences, 875 Howard Street, San \\ Francisco, CA. 94103, USA
}

Received 00-XX-2005. Corrected 00-XX-2005. Accepted 00-XX-2005.

\begin{abstract}
A new species of zephyrinid nudibranch of the genus Janolus Bergh 1884 is described from the Pacific Coast of North America and Costa Rica. J. anulatus sp. nov. differs from other species of Janolus by its external and internal morphology. J. anulatus has a brown or white body with pink, white, and brown spots, smooth papillae epithelium at the base and papillated in the distal part, unbranched digestive gland ducts, smooth jaws, and smooth rachidian and lateral teeth. The species is compared with other species from the Panamic Province and the Western Atlantic. A new extension range of J. barbarensis is documented. Rev. Biol. Trop. 54(4): 1295-1305. Epub 2006 Dec. 15.
\end{abstract}

Key words: mollusca, Nudibranchia, Costa Rica, Janolus.

The genus Janolus Bergh (1884) is comprised of 22 valid species that are distributed in tropical and temperate waters. Six species of the genus Janolus have previously been described from the Atlantic and Pacific coasts of the Americas. Two of these species are present in the Panamic Province and/or Western North America, J. barbarensis (Cooper 1863) from California and Costa Rica and J. fuscus (O'Donoghue 1924) from Canada and California. J. rebeccae (Schrödl 1996) has been described from Chile. Three other species have been described from the Western Atlantic and Caribbean: J. comis Marcus, 1955 from Florida, Curaçao and Brazil, J. mucloc Marcus 1958 from Florida and Brazil and more recently J. costacubensis Ortea and Espinosa 2000 from Costa Rica and Cuba. The present material (a new species and J. barbarensis), constitute two new records of the genus along the Pacific Coast of Costa Rica.

\section{SPECIES DESCRIPTION \\ Genus Janolus Bergh 1884 \\ Janolus anulatus sp. nov}

(Figs 1A;2-5)

Type material: -Holotype- Isla Ballena, Parque Nacional Marino Ballena, Área de Conservación Osa, Puntarenas, Costa Rica (9॰06'24” N, 8343'35” W), 16 January 2000, 1 specimen, $4 \mathrm{~mm}$ preserved length, 6 meters depth, leg. M. Calderón (UCR-INB0001495772); bar code of holotype associated with three components: SEM stub with radula (UCRINB0003764987), SEM stub with a piece of jaw (INB0003764958) and a slide preparation with a piece of jaw (UCR-INB0003765066); PARatypes. - Isla Ballena, Parque Nacional Marino Ballena, Área de Conservación Osa, Puntarenas, Costa Rica $\left(9^{\circ} 06^{\prime} 24^{\prime \prime} \mathrm{N}\right.$, 
$\left.83^{\circ} 43^{\prime} 35^{\prime \prime} \mathrm{W}\right), 16$ January 2000, 1 specimen, 5 mm preserved length, 6 meters depth, leg. M. Calderón (UCR-INB0003764915). Isla Plata, SW side, Guanacaste, Costa Rica (10 $26^{\prime} 48^{\prime \prime}$ N, 85'48'20" W), 17 April 2004, 1 specimen, $4 \mathrm{~mm}$ preserved length, 10 meters depth, leg. Y. Camacho (UCR-INB0003836171); La Jolla California, 1 specimen, $4 \mathrm{~mm}$ preserved length, leg. J. Hamann (CASIZ 170029), La Jolla California, May 1982, 1 specimen 4 mm preserved length (CASIZ 170028).

Geographic range: This species is known from La Jolla, California (Behrens 1991) and the Pacific Coast of Costa Rica (present study).
Etymology: The name of the species "anulatus" refers to a ring that is found near the middle of each dorsal papilla that separates the smooth from the papillate portion.

External morphology: The body is broadest anteriorly, tapering to the acute posterior end of the foot. The rhinophores are perfoliate with about 10 complete or incomplete transverse lamellae. There is a small, convoluted inter-rhinophoral crest (caruncle) between the rhinophores (Fig 2A). The large, bulging cardiac area is located near the middle of the notum. A pair of short, broad, digitiform oral tentacles extends from either side of the head. The dorsal papillae are stout and cup-shaped
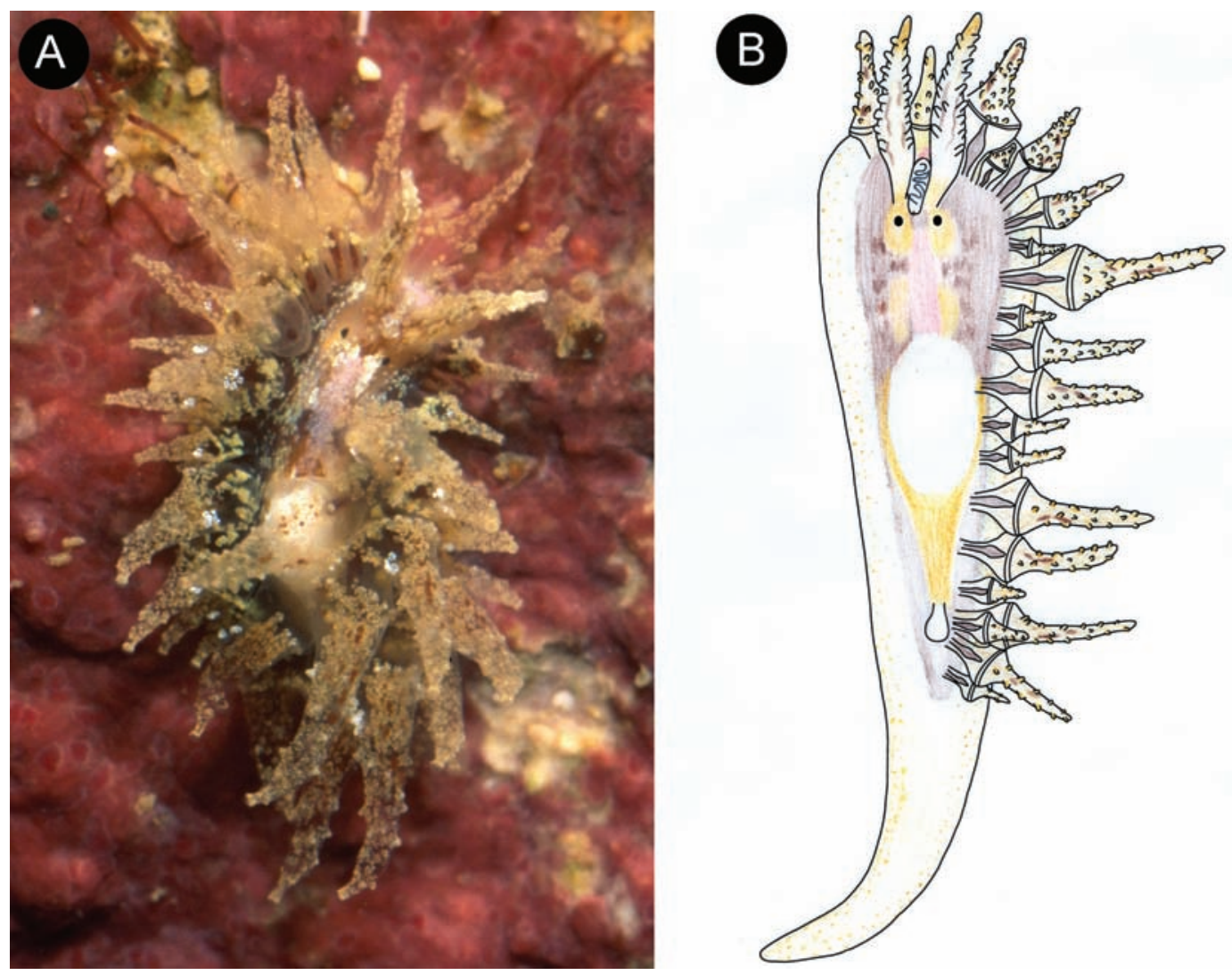

Fig. 1A. Photograph of the living animal of $J$. anulatus sp. nov., Costa Rica (INB0001495772). B. Drawing of the living animal of J. anulatus sp. nov., Costa Rica (INB0001495772). Photograph of the living animal of J. barbarensis, Costa Rica (INB0001496134). B. Drawing of the living animal of J. barbarensis Costa Rica (INB0001496134). 
with a long prolongation at the apex. The base of each papilla is smooth, followed by a ring and numerous small papillae that extend the length of each papilla (Fig 2C). The papillae are arranged in two longitudinal rows of up to 25 papillae. The digestive gland inserts into the papillae at a point just below or just above the ring of the papilla. The digestive gland does not branch. The anus is located mid-dorsally near the posterior end of the dorsum (Fig 2D). A large anal gland is present below the anus. The gonopore is located on the right side in the middle of the body, while the nephroproct is situated more posteriorly.

In some specimens, the background color of the dorsum bears two colors: the anterior half dark brown, the posterior half light brown. In others, the background color is white with some brown spots (Fig 1A). Around the eyes, there is a translucent light cream mask. A pink spot extends from behind the rhinophores to the anterior part of the cardiac area. There is another pink spot in front of the rhinophores with two opaque white spots to the sides. The cardiac area is opaque white in color. The anus is opaque white with a small stalk. Rhinophores are dark cream with light apices and some central dark brown spots. The inter-rhinophoral crest is opaque white with a few cream spots. The digestive gland within the papillae is chocolate brown. The background color of the papillae is light cream with some large brown and opaque white spots. The smaller papillae on the digestive gland are yellow. There are some green reflective specks distributed homogenously on the body. Dorsally, the foot
A

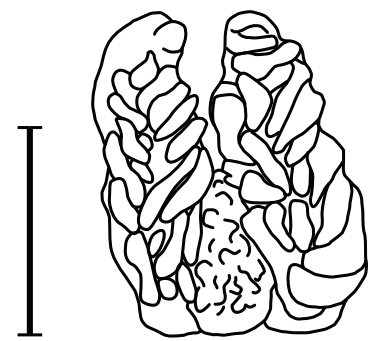

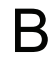

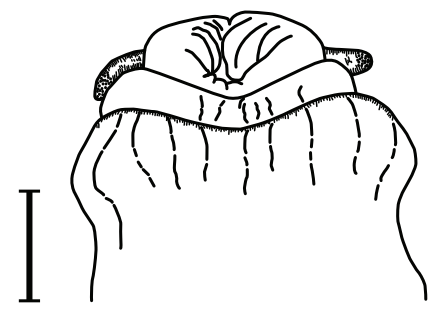

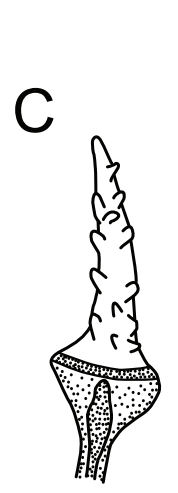

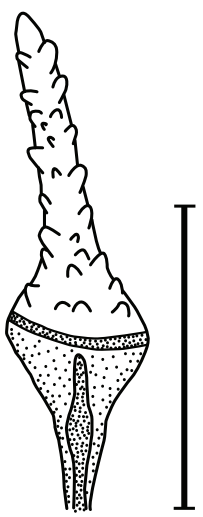

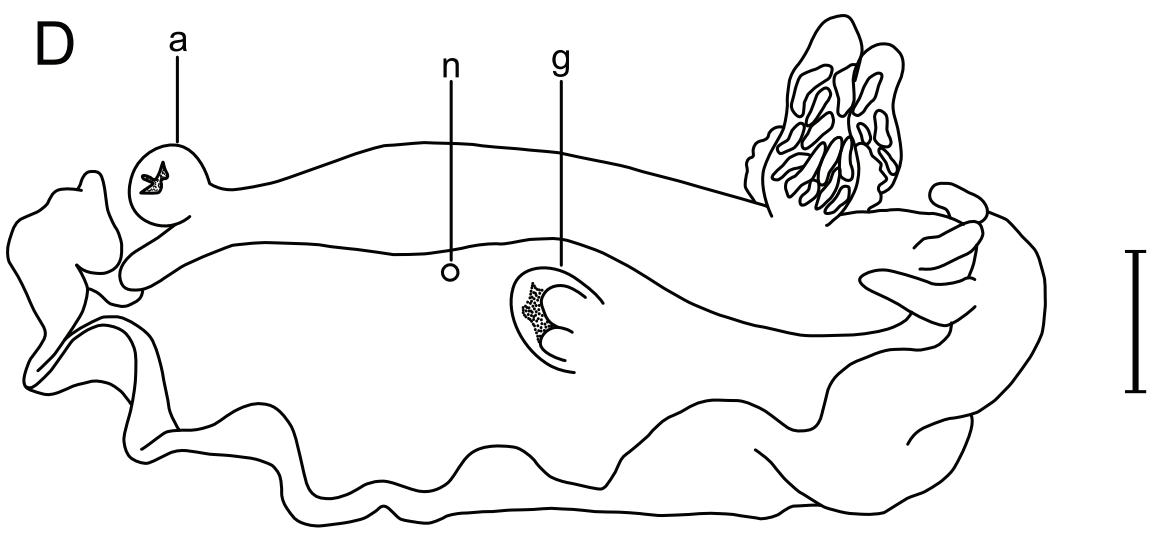

Fig. 2A. Rhinophores and inter-rhinophoral crest of $J$. anulatus sp. nov., scale bar $=1 \mathrm{~mm}$. B. Mouth, scale bar= $1 \mathrm{~mm} . \mathrm{C}$. Detail of dorsal papillae of $J$. anulatus sp. nov., scale bar $=1 \mathrm{~mm}$. D. Lateral view of body, scale bar $=1 \mathrm{~mm}$, Abbreviations: $\mathrm{a}=$ anus, $\mathrm{g}=$ gonopore, $\mathrm{n}=$ nephroproct, scale $\mathrm{bar}=1 \mathrm{~mm}$. 
is translucent with very small cream-colored spots around the margins. Ventrally, the mouth has numerous light brown specks, the oral tentacles are opaque white, and the foot bears cream specks.

Anatomy: The buccal mass is large and muscular with an oval opening and with small anterior oral glands in front of it (Fig. 3A). The strong jaws are amber in color. They are joined together and are devoid of any serial denticles (Fig 3B, 5D). The inner masticatory border is thick and smooth.

The radular formula is $13 \times(19.1 .19)$ in a $4 \mathrm{~mm}$ preserved length specimen. The rachidian teeth are small and somewhat amorphous in shape, without denticles (Fig. 5A). The inner lateral teeth are hook shaped, smooth, and arched (Fig. 5B). They gradually become larger from the innermost to the mid-laterals, then become smaller from the mid-laterals to the hook-shaped outermost teeth (Fig 5C).

The ampulla is thick and convoluted. It narrows into the bifurcation of the vas deferens

A

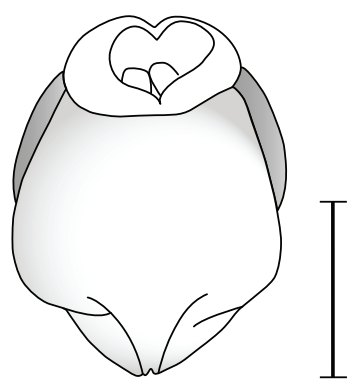

B

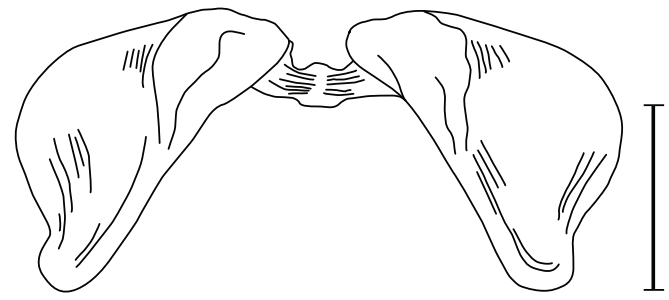

Fig. 3A. Buccal mass of $J$. anulatus sp. nov., scale bar= $1 \mathrm{~mm}$. B. Jaw of $J$. anulatus sp. nov., scale bar $=1 \mathrm{~mm}$. and the thin oviduct. The distal vas deferens is short and enlarges into a much thicker, curved prostate. The prostate narrows into a convoluted ejaculatory duct that connects to the large, conical, unarmed penis (Fig 4). The oviduct is short and expands into a tubular serial seminal receptacle. This duct again narrows and widens into the muscular, kidney-shaped vagina. A tubular bursa copulatrix enters the female atrium near its junction with the oviduct. The female gland mass is oval and exits into the female atrium.

Remarks: J. anulatus sp. nov. differs from other species of the genus Janolus from the Panamic Province and the Western Atlantic in its internal and external morphology (Table 1). $J$. anulatus is characterized by having a brown or white body with pink, white, and brown spots, smooth papillae epithelium at the base and papillated in the distal part of each papilla, unbranched digestive gland ducts within the dorsal papilla, smooth jaws, and smooth rachidian and lateral teeth.

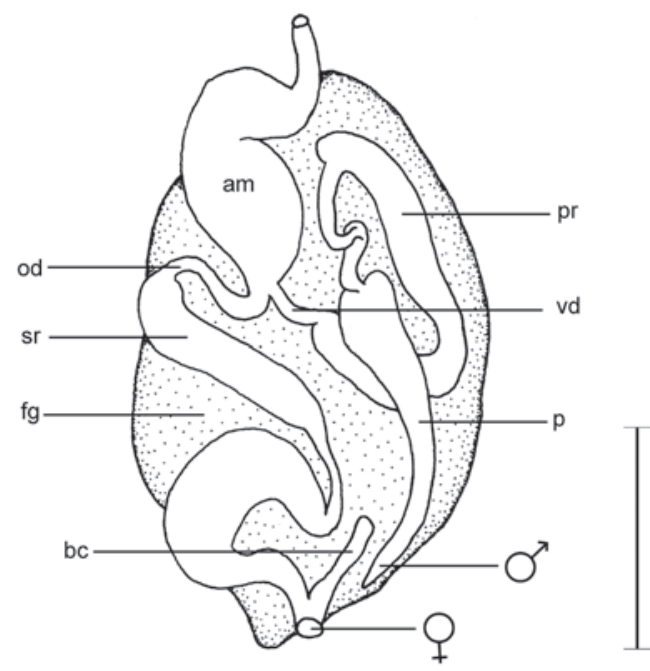

Fig. 4. Reproductive system of $J$. anulatus sp. nov. (INB0001495772), scale bar $=1 \mathrm{~mm}$. Abbreviations: $\mathrm{am}=$ ampulla, $\mathrm{bc}=$ bursa copulatrix, $\mathrm{fa}=$ female atrium, $\mathrm{fg}=$ female gland, $\mathrm{mg}=$ male gonopore, ov= oviduct, $\mathrm{p}=$ penis, $\mathrm{pr}=$ prostate, $\mathrm{sr}=$ seminal receptacle, $\mathrm{vd}=\mathrm{vas}$ deferens. 
In

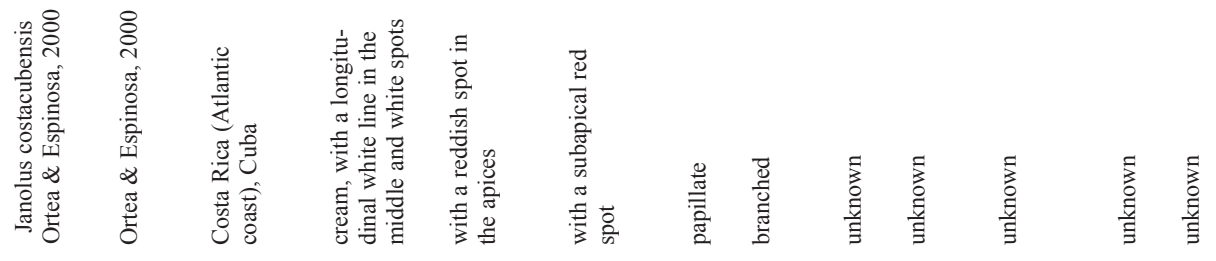

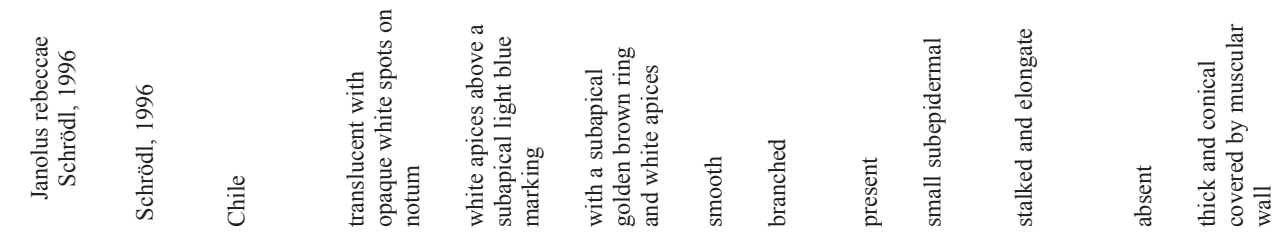

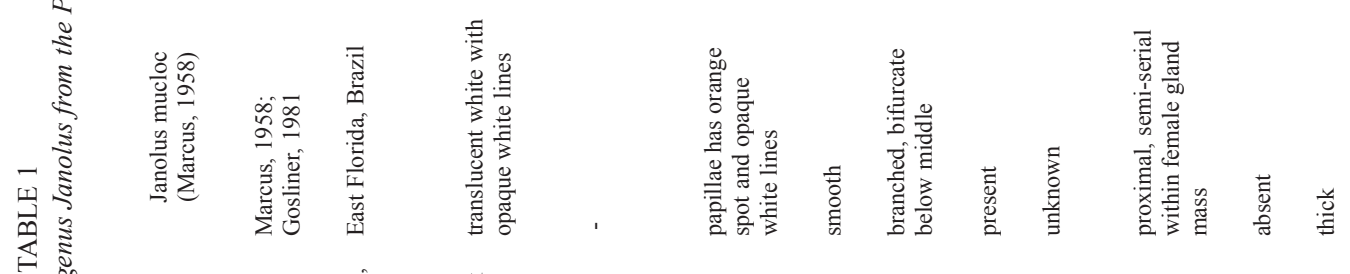

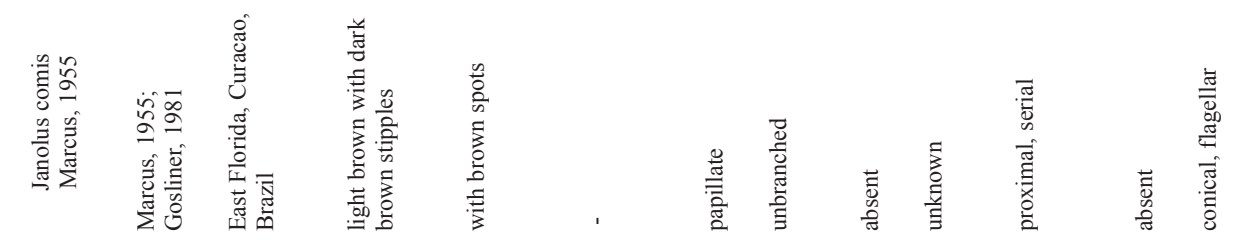

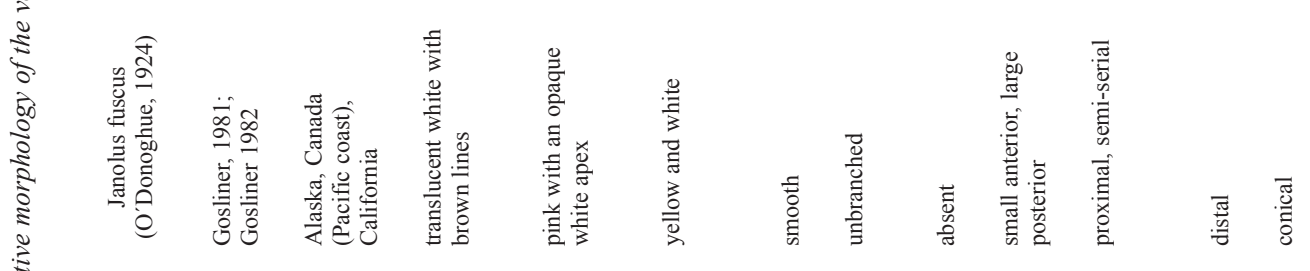
In $\|$ In 


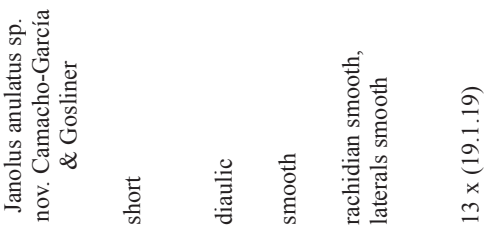

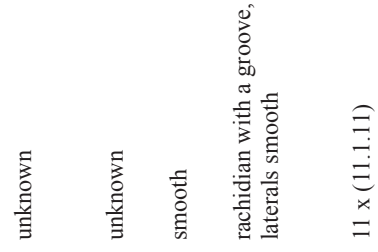

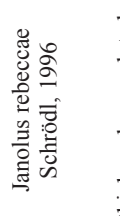

号

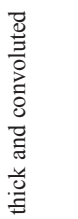
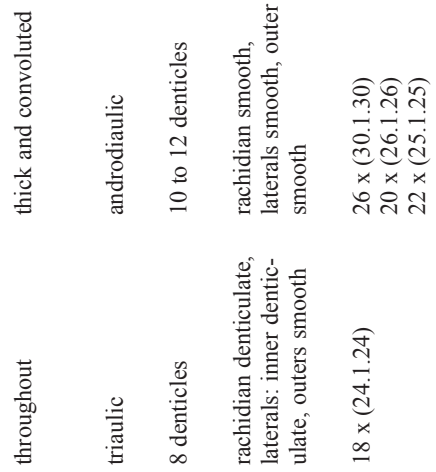
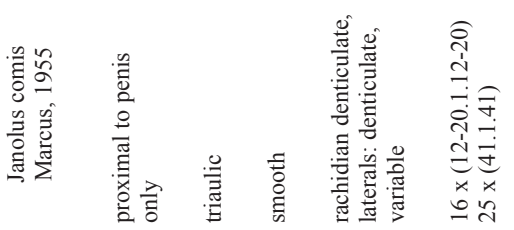

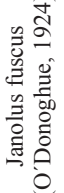
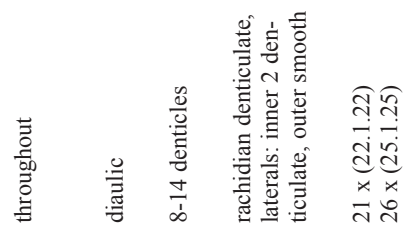
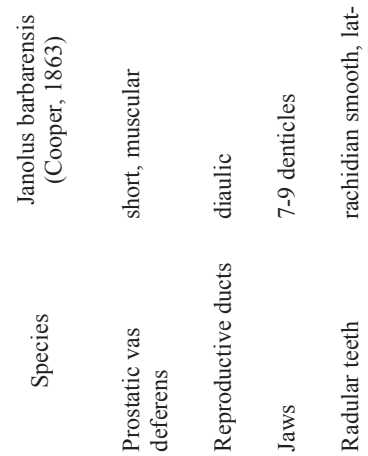

$J$. barbarensis and J. costacubensis, two species present along the Pacific and Caribbean coasts of Costa Rica, respectively, differ from $J$. anulatus. J. barbarensis has a translucent white body with gold and blue cerata, markings on the dorsal papillae with branched digestive gland ducts, jaws with denticles, and lateral teeth with denticles. J. costacubensis has a cream body with a longitudinal white line, rhinophores with papillae on the bases, and lamellae in the distal part of the rhinophores. In this species, the entire epithelium of the dorsal papillae bears papillae, while in $J$. anulatus only the apical portion above the ring bears papillae. The digestive gland in the papillae of $J$. costacubensis extends for more of the length than does that of $J$. anulatus.

Of the six species of $J$. described from the Americas, only $J$. comis and $J$. costacubensis have dorsal papillae with a papillate rather than smooth surface. These two species, together with $J$. anulatus, are also the only American taxa with a smooth margin on the jaws.

$J$. fuscus differs from $J$. anulatus on the basis of its radular, external, and internal morphology. J. fuscus has a translucent white body with brown lines, yellow and white papillae, smooth papilla epithelium, jaws with 8 to 14 denticles, and denticulate rachidian and lateral teeth. This species lacks anal glands, which are present in $J$. anulatus.

Behrens (1991) and Camacho-García et. al (2005) published a photo of a species of Janolus from La Jolla, California (as Janolus sp. 1, page 82) and from México and Costa Rica (as Janolus sp., page 98). This species corresponds to the same species we are describing in this paper.

$J$. comis resembles $J$. anulatus in that its epithelium of the dorsal papillae is papillated, but differs in that it lacks an anal gland and has denticulated rachidian and lateral teeth. It also lacks a bursa copulatrix.

$J$. rebeccae differs externally from $J$. anulatus by the presence of a white line on the posterior end of the foot, branched digestive gland ducts, and numerous smooth dorsal papillae, which have a golden brownish ring below the 


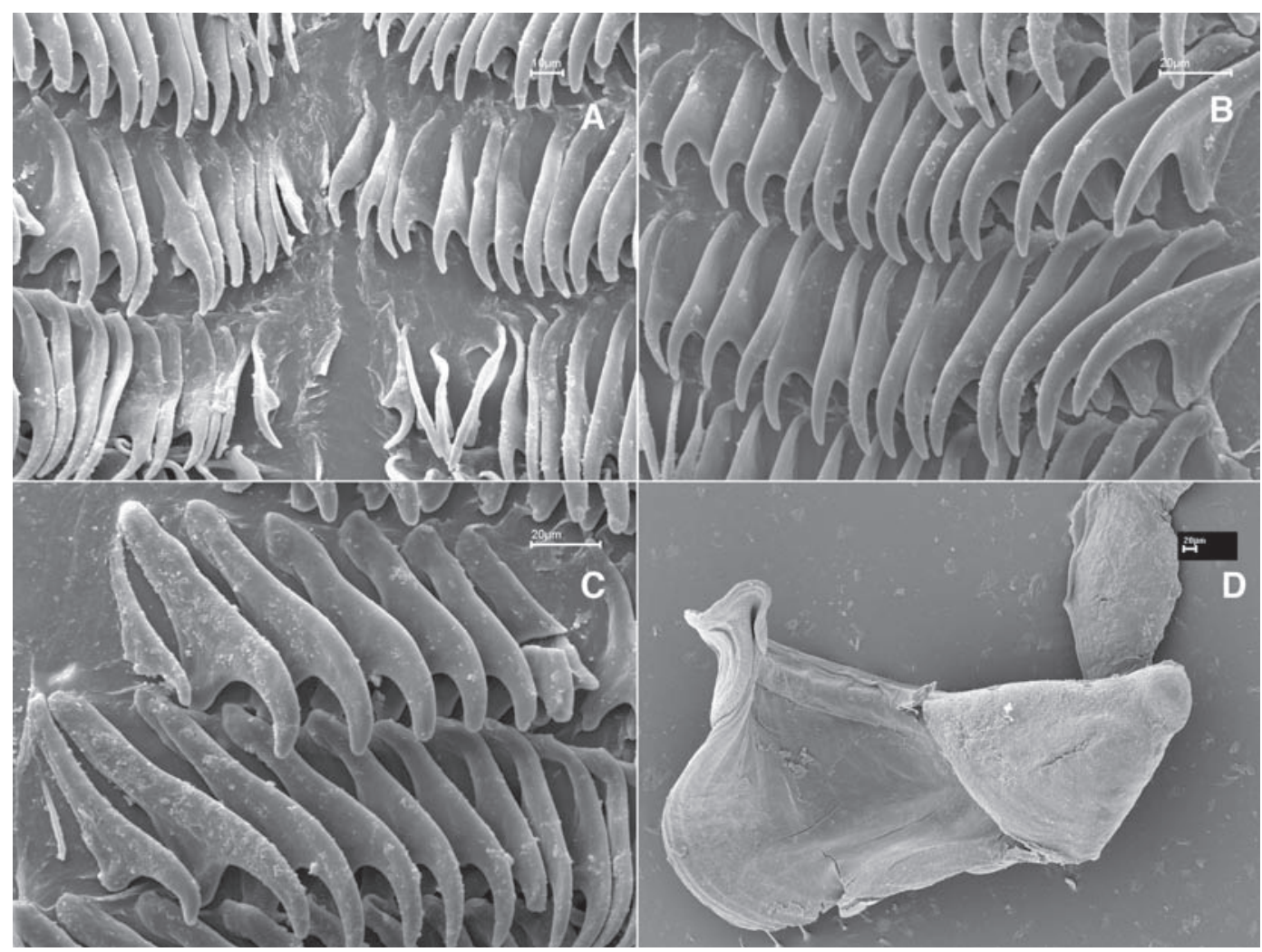

Fig. 5. Scanning electron micrographs of J. anulatus sp. nov. (INB0001495772). A. Innermost radular teeth, scale bar $=10 \mu \mathrm{m}$. B. Midlateral radular teeth; scale bar $=20 \mu \mathrm{m}$. C. Outermost radular teeth, scale bar $=20 \mu \mathrm{m}$. D Jaw, scale bar $=20 \mu \mathrm{m}$.

white-tipped papilla. $J$. rebeccae externally resembles $J$. barbarensis but differs to some extent in internal morphology and radular features discussed in detail by Schrödl (1996).

J. chilensis Fischer, Cervera and Ortea 1997, another species described from Chile, is considered a junior synonym of $J$. rebeccae (Cervera 1997). However, Schrödl (2003) considered both species different due to differences in their reproductive system. More material from Chile needs to be examined.

J. hyalinus (Alder and Hancock 1854), a species present in the Atlantic and Mediterranean waters of Europe, also resembles $J$. anulatus because of the presence of papillae on the dorsal papillae. However, this species has many more dorsal papillae and these are more elongated and evenly shaped than those of $J$. anulatus, which has unevenly tapered papil- lae with more prominent tubercles. $J$. hyalinus also has a semiserial receptaculum seminis, while $J$. annulatus has a serial one and a distal bursa copulatrix, which is absent in J. hyalinus (Schmekel 1970).

\section{Janolus barbarensis \\ (Cooper 1863) \\ (Figs 1B, 6-7)}

Aeolis barbarensis Cooper 1863:59.

Antiopella coeruleopictus Cockerell and Eliot 1905, O’ Donoghue 1922.

Antiopella aureocincta Johnson and Snook 1927; Steinberg, 1963, nomen dubium.

Antiopella aureotincta MacGinitie and MacGinitie 1949; Steinberg 1963, nomen dubium. Antiopella aureocincta MacFarland 1966, in part. J. barbarensis (Cooper, 1863); O’Donoghue 1922. 
Material examined: West side of Isla Ballena, Parque Nacional Marino Ballena, Área de Conservación Osa, Puntarenas, Costa Rica

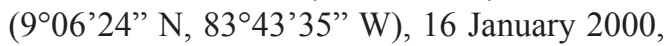
1 specimen, $4 \mathrm{~mm}$ preserved length, 6 meters depth, leg. M. Calderón (INB0001496134).

Geographic range: Central California to Bahía San Quintín, Baja California, the Gulf of California, México, and Costa Rica (present study).

Natural History: It has been found on the upper surface of rocks in 6 meters deep.

External morphology: The body is broadest anteriorly, tapering to the acute posterior end of the foot. The rhinophores are smooth basally and perfoliate distally with about 13 complete or incomplete transverse lamellae. The inter-rhinophoral crest located between the rhinophores is hourglass shaped, and moderately convoluted (Fig 1D and 6A). A pair of short, broad, digitiform oral tentacles extends from either side of the head (Fig 6B). The smooth dorsal papillae are stout, wider in the middle, and have a short prolongation at the apex (Fig 2C). In the specimen examined, the papillae are arranged in about two rows on either side of the body, with two papillae per row. The digestive gland inserts into the papillae at the base and branches irregularly within the papilla. The anus is located mid-dorsally near the posterior end of the dorsum (Fig 6D). The large gonopore is located on the right side in the middle of the body. A large anal gland is present below the anus.

The living animal of the specimen examined is translucent orange with a number of small brown specks homogeneously distributed over the dorsum. The inter-rhinophoral crest is pinkish. The light brown greenish pigment of the digestive gland is visible within the cerata. The ceratal surface bears an orange-yellow subapical band and a bluish white apical band. The middle part of each rhinophore is light yellow with black spots; a number of minute brownish spots is located at the base of each rhinophore. The anus has a white ring around it. Dorsally, the foot is translucent white with a light blue line extending to the posterior end. Ventrally, the foot is light orange.

Anatomy: The buccal mass is large and muscular with an oval opening and small anterior oral glands (Fig. 6E). The strong jaws are amber in color. They are joined together and have at least 7 strong and wide rectangular denticles around the masticatory border (Fig 7D).

The radular formula is $14 \mathrm{x}(15.1 .15)$ in a 4 $\mathrm{mm}$ preserved length specimen. The rachidian teeth are narrow with a pointed cusp, without denticles (Fig. 7A). The inner lateral teeth are hook shaped, smooth, and arched (Fig. 7B). They gradually become larger from the innermost to the mid-laterals, then become smaller from the mid-laterals to the hook-shaped outermost teeth (Fig 7C).

The reproductive system of the specimen was studied. However, some of the parts were not well developed because the specimen was immature. The ampulla is tubular and short. It narrows to the bifurcation of the vas deferens and oviduct. The vas deferens is short and convoluted. It narrows into a pear-like shaped penis (Fig 6F). The oviduct is short and expands into a tubular duct where the seminal receptacle is not clearly differentiated. This duct again narrows and widens into a globular bursa copulatrix and a globular vagina. The female gland mass is amorphous in shape and exits near into the female atrium.

Natural History: This species was found in the subtidal zone around 6 meters depth where it feeds on ramified bryozoans.

Remarks: The internal and external morphology of the single specimen collected in Costa Rica perfectly fits with the description of J. barbarensis (Cooper 1863) in Gosliner (1982). Gosliner found and discussed in detail several consistent differences in the external morphology, coloration, digestive system and reproductive system that confirms that $J$. barbarensis is a distinct species from $J$. fuscus, another species found along the California coast. 
A

B
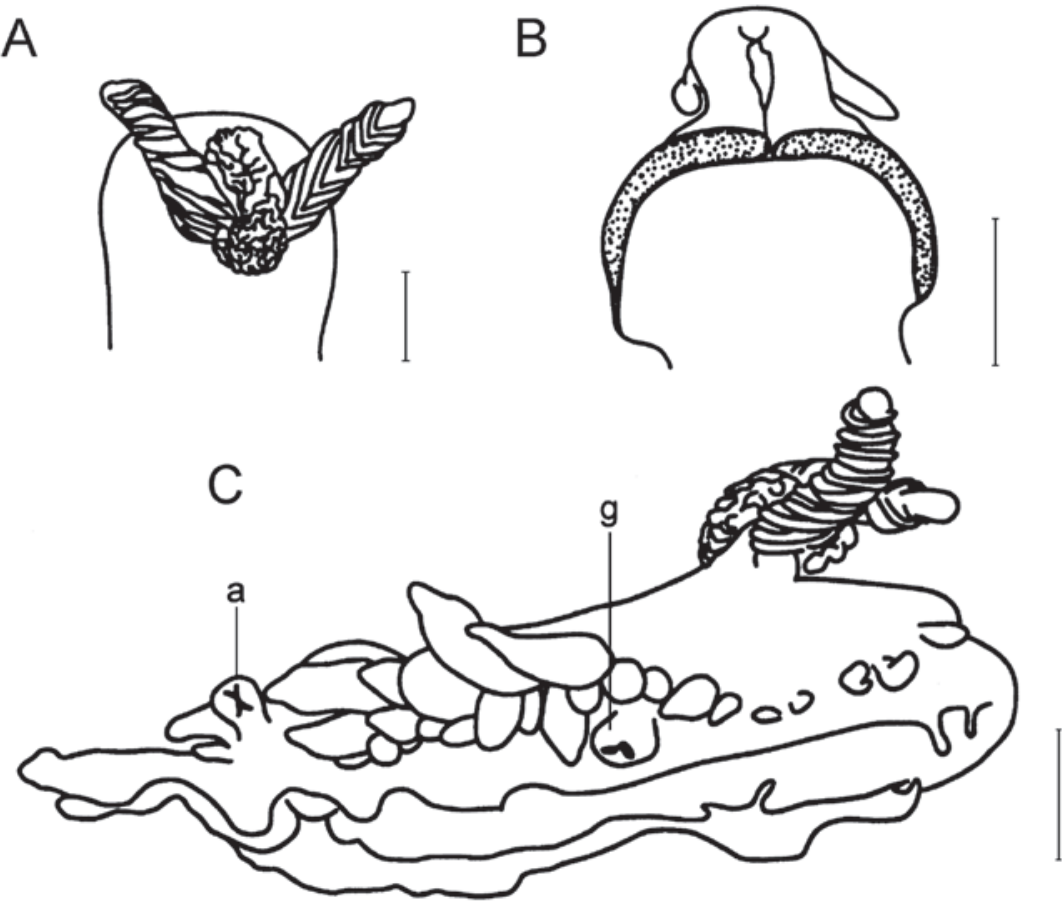

$\mathrm{D}$
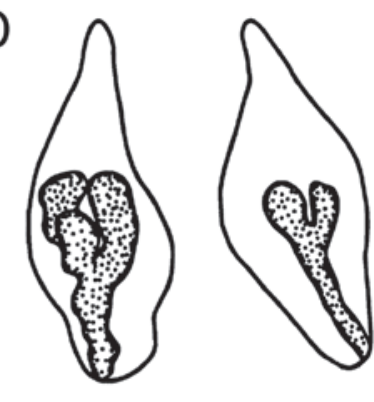

E

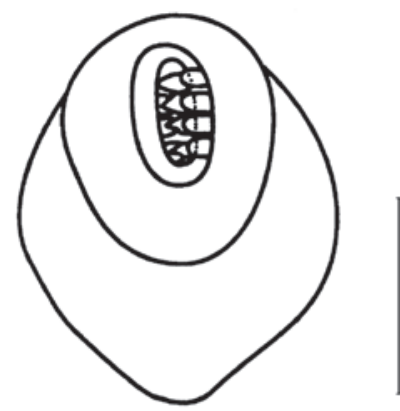

$\mathrm{F}$

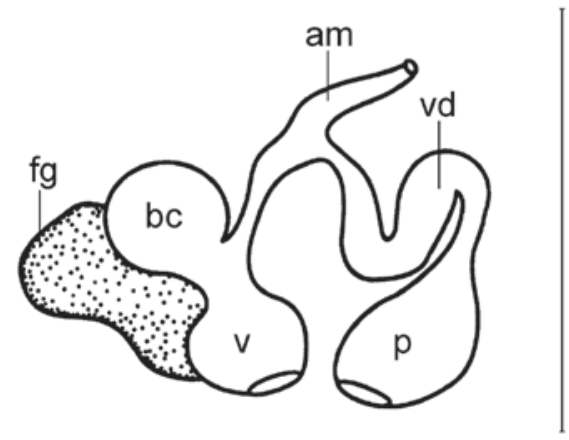

Fig 6. Rhinophores and inter-rhinophoral crest of J. barbarensis (INB0001496134), scale bar= $1 \mathrm{~mm}$. B. Mouth, scale bar= $1 \mathrm{~mm}$. C. Lateral view of body, scale bar $=1 \mathrm{~mm}$, Abbreviations: $\mathrm{a}=$ anus, $\mathrm{g}=$ gonopore, scale bar $=1 \mathrm{~mm}$. D. Detail of dorsal papillae, scale bar $=1 \mathrm{~mm}$. E. Buccal mass, scale bar $=1 \mathrm{~mm}$. F. Reproductive system, scale bar $=1 \mathrm{~mm}$. Abbreviations: $a m=$ ampulla, $b c=$ bursa copulatrix,$f g=$ female gland, $p=$ penis, $v=$ vagina, $v d=$ vas deferens . 


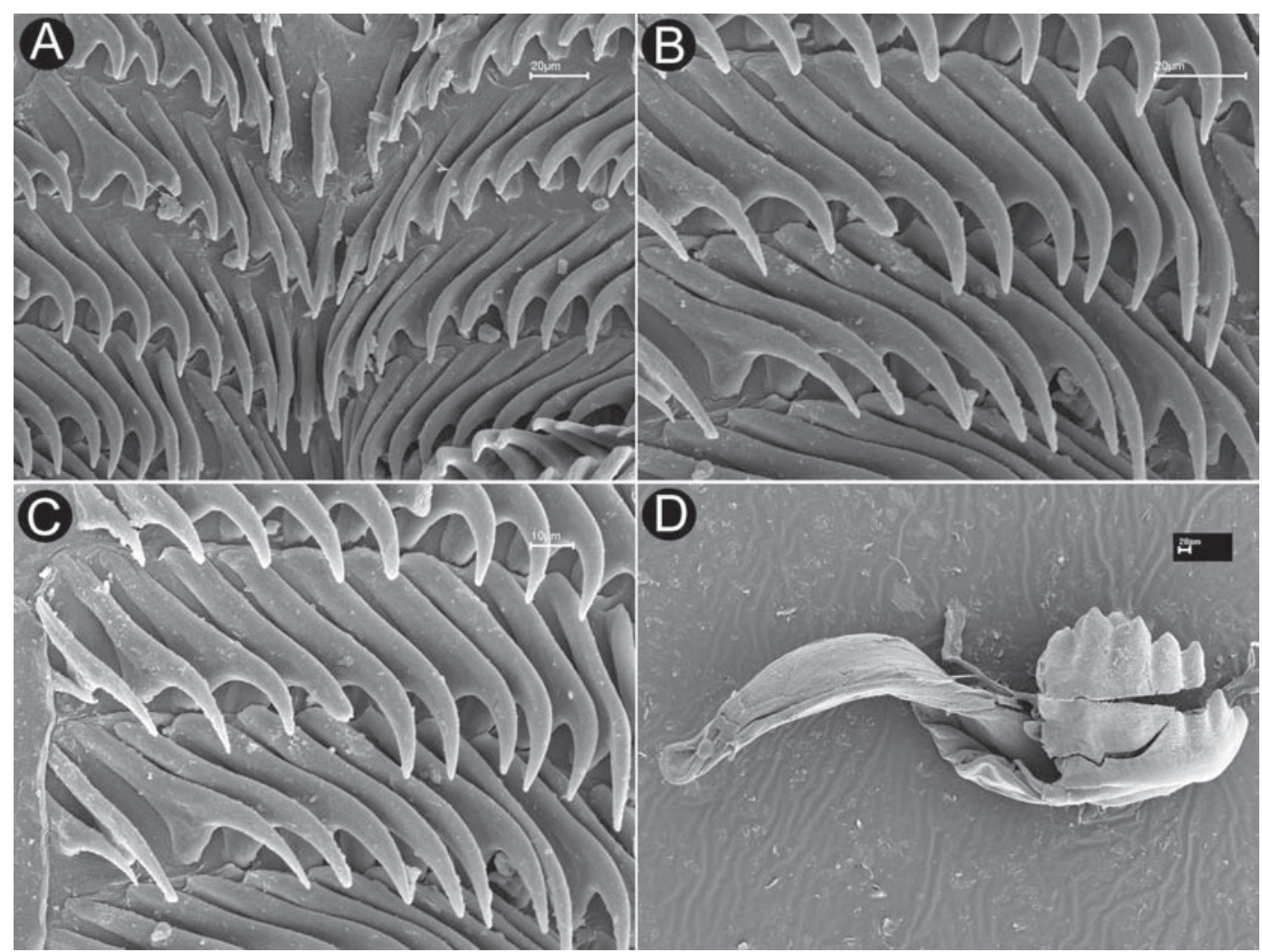

Fig. 7. Scanning electron micrographs of J. barbarensis (INB0001496134). A. Innermost radular teeth, scale bar $=20 \mu \mathrm{m}$. B. Midlateral radular teeth; scale bar $=20 \mu \mathrm{m}$. C. Outermost radular teeth, scale bar $=10 \mu \mathrm{m}$. D Jaw, scale bar $=20 \mu \mathrm{m}$.

\section{ACKNOWLEDGMENTS}

This paper has been supported in part by the National Science Foundation through the PEET 0329054 "Phylogenetic systematics of nudibranchia," to Terrence M. Gosliner and Ángel Valdés and the California Academy of Sciences. The fieldwork in Costa Rica was funded by the Instituto Nacional de Biodiversidad (INBio). Maribel Zúniga helped with some technical aspects of the paper. David Butvill made constructive comments to this manuscript.

\section{RESUMEN}

Una nueva especie de nudibranquio zefirínido del género Janolus Bergh 1884 es descrita de la costa pacífica de Norte América y Costa Rica. J. anulatus sp. nov. difiere de otras especies de Janolus por su morfología externa e interna. $J$. anulatus tiene un cuerpo café o blanco con manchas rosadas, blancas o cafés, papila del epitelio lisa en la base y con papilas en la parte distal, ductos de la glándula digestiva no ramificados, mandíbulas lisas y dientes laterales y raquidios lisos. La especie es comparada con otras especies de la Provincia Panámica y el Atlántico Oeste. Una nueva extensión de ámbito de $J$. barbarensis es documentada.

Palabras clave: Mollusca, Nudibranchia, Costa Rica, Janolus.

\section{REFERENCES}

Behrens, D. 1991. Pacific coast nudibranchs: A guide to the opisthobranchs of the northeastern Pacific. Sea Challengers, Los Osos, California. 112 p.

Bergh, L.S.R. 1884. Report on the Nudibranchiata dredged by H.M.S. Challenger during the years 1873-1876. Report of the Scientific Results of the Voyage of H.M.S. Challenger during the years 1873-76, under 
the command of Captain George S. Nares, R.N., F.R.S. and Captain Frank Tourle Thomson, R.N. prepared under the superintendence of the late Sir C. Wyville Thomson, Knt., F.R.S., \&c. Regius Professor of Natural History in the University of Edinburgh Director of the Civilian Scientific Staff on board, and now of John Murray one of the naturalists of the expedition, Zoology 10 (26): 1-154, pls. 1-14.

Camacho-García, Y., T. Gosliner \& A. Valdés. 2005. Fieldguide to the Sea slugs of the Tropical Eastern Pacific. California Academy of Sciences, California. Allen Press Inc. 129 p.

Cervera, L. 1997. Janolus chilensis junior synonym of $J$. rebeccae Schrödl, 1996. Opisthobr. Newsl. 23:29.

Cooper, J.G. 1863. On new or rare Mollusca inhabiting the coast of California. No. II. Proc. Cal. Acad. Sci. 3: $56-60$

Gosliner, T. 1981. The South African Janolidae (Mollusca, Nudibranchia) with the description of a new genus and two new species. Ann. S. Afr. Mus. 86: 1-42.

Gosliner, T. 1982. The genus Janolus (Nudibranchia: Arminacea) from the Pacific coast of North America, with a reinstatement of Janolus fuscus O'Donoghue, 1924. Veliger 24: 219-226.

Johnson, M.E. \& H.J. Snook. 1927. Sea shore animals of the Pacific coast. MacMillan Co., New Cork. $659 \mathrm{p}$.
MacFarland, F. 1966. Studies of opisthobranchiate mollusks of the Pacific coast of North America. Mem. Cal. Acad. Sci. 6: 546 p.Marcus, Er. 1955. Opisthobranchia from Brazil. Boletim da Faculdade de Filosofia, Ciencias e Letras, Universidade de São Paulo, Zoologia, 207, 20:89-261, pls. 1-30.

Marcus, Er. 1958. On western Atlantic opisthobranchiate gastropods. Amer. Mus. Nov. (1906): 1-82.

O’Donoghue, C.H. 1922. Notes on the taxonomy of nudibranchiate Mollusca from the Pacific coast of North America. Proc. Malacol. Soc. Lond. 15: 133-150.

Ortea, J. \& J. Espinosa. 2000. Nueva especie del género Janolus Bergh, 1884 (Mollusca: Nudibranchia) de Cuba y Costa Rica. Avicennia 12/13: 79-83.

Schmekel, L. 1970. Anatomie der Genitalorgane von Nudibranchiera. (Gastropoda Euthyneura). Pubbl. Staz. Zool. Nap. 38: 120-217.

Schrödl, M. 1996. Janolus rebeccae, a new species of arminacean nudibranch from northern Chile. Spixiana 19: 293-300.

Schrödl, M. 2003. Sea Slugs of Southern South America.: Systematics, Biogeography and Biology of Chilean and Magellanic Nudipleura (Mollusca: Opisthobranchia). ConchBooks. Germany. 165 p.

Steinberg, J.E. 1963. Notes on the opishobranchs of the west coast of North America. III. Further nomenclatorial changes in the order Nudibranchia. Veliger 6: 63-67. 
